\title{
"Parei na contramão": faixas cruzadas na invenção da MPB
} "I stopped in the wrong side":
criss-crossed tracks in the invention of MPB Álvaro Neder

Para a compreensão da história do Brasil na década de 1960, muitos autores têm-se utilizado da canção popular (para nos restringirmos a trabalhos realizados por historiadores, ver, por exemplo, Contier, 1998, e Napolitano, 2001). A justificativa para tal procedimento se baseia no fato de que a canção popular explicita relações entre as subjetividades e a vida pública mais ampla, tornando-se documento histórico dos conflitos políticos, institucionais, sociais e econômicos vividos pela sociedade brasileira como um todo, e ao mesmo tempo permite entrever identidades, sonhos e perspectivas de sujeitos empíricos concretos e situados.

A busca de tal conhecimento sobre o contexto, sem perder de vista o universo subjetivo, por meio do exame da música popular, requer, então, uma sele-

\footnotetext{
Álvaro Neder é doutor em Letras pela PUC-Rio e em Música pela Unirio, e atua na graduação e na pós-graduação do IFRJ (alvaroneder@ig.com.br).

Artigo recebido em 30 de dezembro de 2011 e aprovado para publicação em 23 de março de 2012.
} 
ção de métodos que possam dar conta das esferas discursivas tanto "extramusicais" quanto propriamente musicais. Isto porque, apesar da fundamental importância dos sentidos veiculados por fatos e suas interpretações, por letras de música e o que se diz sobre elas, o momento em que os sons impactam o corpo-individual e social - continua sendo visto como crucial pelos sujeitos implicados. Em vista disso, privilegiou-se uma seleção de métodos - histórico e etnográfico - e de técnicas - exame de documentos, observação participante, entrevistas e análise de canções à luz da etno/musicologia. Por meio de tal seleção, procurou-se desconstruir uma narrativa hegemônica, que, pouco a pouco, se consolidou na historiografia e na crítica cultural do período.

Essa narrativa tem seu primeiro impulso de peso com o livro Balanço da bossa e outras bossas, organizado por Augusto de Campos (1974a). Com uma linguagem militante, críticos literários à frente da vanguarda concretista e músicos ligados ao grupo Música Nova empenharam-se em opor MPB e Tropicália. Por isso, o livro seria abertamente "contra" a MPB, alcunhada por Campos de TFM ("Tradicional Família Musical”).

Em oposição à $\mathrm{MPB}$, vista como retrógrada, preconceituosa e fechada a mudanças, emerge da coletânea uma visão evolucionista e eurocêntrica da música popular brasileira que enaltece e mitifica a bossa nova e a Tropicália como expressões de uma arte "moderna".

A música popular brasileira, anteriormente ao advento da bossa nova, estava, inegavelmente, mais de meio século atrasada em relação à erudita. Hoje pode-se afirmar que houve uma considerável diminuição desse distanciamento, e isto graças principalmente à concepção musical bossa nova. (Rocha Brito, 1974: 27)

Nessa hierarquização evolucionista, o "exagero" da MPB representaria uma involução, uma

fase até de regresso, pois é indubitável que a "teatralização" da linguagem musical (correspondendo a certas incursões compositivas no gênero épico-folclórico) se vincula às técnicas do malsinado bel canto de que a BN parecia nos ter livrado para sempre. (Campos, 1974b: 56)

Um ponto de contato essencial entre Balanço da bossa e outras bossas e as propostas tropicalistas é a posição, também evolucionista, expressa por Caetano 
Veloso no debate divulgado pela Revista Civilização Brasileira em 1966: "Só a retomada da linha evolutiva pode nos dar uma organicidade para selecionar e ter um julgamento de criação" (citado por Campos, 1974c: 143). Como se sabe, Caetano delimitava as transformações efetuadas sobre o samba pela bossa nova para prescrever o caminho que deveria ser seguido pela música popular brasileira como um todo. No entanto, centrada no samba e nos procedimentos técnicos e estéticos da bossa nova, tal concepção, além de evolucionista, não poderia deixar de afirmar uma noção ideológica e excludente de identidade nacional. É sob tais pressupostos que o livro de Campos busca afirmar a Tropicália como o estágio mais evoluído da música popular brasileira naquele momento.

Transparecem, assim, opções estético-ideológicas de setores dominantes. Tais setores desconsideram a participação das classes populares na nascente MPB, atribuindo a súbita emergência de padrões interpretativos e composicionais tradicionais a uma atitude folclórica e nacionalista vinda "de cima".

Buscando problematizar essa narrativa, pretende-se aqui desenvolver as proposições que seguem. Não se pode limitar os ouvintes da MPB inicial ao público universitário, porque esse movimento, distanciando-se das proposições estéticas elitizadas da bossa nova e atendendo a expectativas tradicionais populares, atraiu uma faixa mais ampla da população.

Além disso, essa MPB inicial foi palco de outras disputas políticas, para além do nacional-popular. Foi com a MPB e Jorge Ben que, pela primeira vez, a música popular brasileira articulou um discurso musical - não apenas através das letras - que inscreveria posições identificadas com o ideário da negritude diaspórica transnacional, questionando a ideologia da mestiçagem. A atividade das mulheres na MPB - especialmente Nara Leão - também pode ser estudada nos termos de um desafio ao controle patriarcal.

Finalmente, há evidências de que o público da MPB passou a se confundir com o público da Jovem Guarda - e depois, da Tropicália - por meio de uma complexa construção identitária, apesar de ser notória a influência do nacionalismo. Como evidência desta afirmação, é apresentado o depoimento de uma ex-militante do PC do B.

Um breve retrospecto é necessário. Em 1958, a Declaração sobre a política do PCB procurou unir os setores populares a segmentos "progressistas" da burguesia como forma de conter o avanço do imperialismo, com a adesão de intelectuais e artistas. Com o surgimento da linha politizada de Carlos Lyra e Sérgio Ricardo, entraria em cena a chamada "bossa nova participante", que se diferencia- 
ria da $\mathrm{BN}$ por seu caráter ativista e vinculado às causas sociais. Com o "Manifesto do Centro Popular de Cultura da União Nacional dos Estudantes”, o CPC da UNE, lançado em outubro de 1962, estabeleceu-se, entretanto, uma clivagem. Enquanto os músicos buscavam manter as conquistas estéticas da $\mathrm{BN}$, utilizando-as como a base de um novo gênero em que figurariam letras participantes e engajadas, os ideólogos do CPC tentavam disciplinar a criação dos músicos impondo-lhes o caminho do folclore.

Frente a esse programa demasiado estreito, os artistas comprometidos com a busca de "modernização" da música popular dentro de uma orientação nacionalista procurariam outro caminho, em tensão com a orientação do CPC. Além dos citados Lyra e Ricardo, Baden Powell, Vinicius e outros letristas e compositores acreditavam que a música popular, além de servir a um propósito ideológico, deveria também manter um compromisso pedagógico com o aprimoramento da sensibilidade popular.

Entretanto, na medida em que desconsideraram a sobrevivência material das produções em uma indústria cultural capitalista, a historiografia e crítica atribuíram um poder de determinação desproporcional aos ideólogos ou compositores. Mesmo quando surgiam gravações de gêneros e estilos mais populares que são tradicionalmente descritas como obedecendo à "estética do CPC" -, isso seria devido, mais uma vez, exclusivamente às intenções soberanas da elite cultural, suficientes para impor seus desejos aos grandes conjuntos sociais, invisíveis no processo.

Tais conjuntos são mais facilmente observáveis por trás do sucesso popular de artistas que não se alinhavam ao pensamento da esquerda. Ainda assim, vinculavam-se ao samba e outros gêneros populares, não como tentativa pedagogizante e paternalista de converter os setores subalternos da população, e sim como expressão cultural própria desses setores e/ ou mera busca de sucesso popular.

Bastante sintomáticos nesse sentido são os álbuns Samba esquema novo, de Jorge Ben, e Ellis Regina, de Elis Regina, ambos lançados no mesmo ano de 1963. Esses álbuns, portanto, precederam o golpe de 64 e todos os espetáculos de teatro marcados pela participação estudantil, como O Fino da Bossa $(25 / 5 / 1964)$, Opinião (11/12/1964) e Arena Conta Zumbi (1/5/1965).

O álbum de Jorge Ben evidencia a busca de uma alternativa artístico-comercial à bossa nova desde seu título, embora o gênero seja utilizado no álbum. Nesse sentido, pode ser visto como a busca de um "esquema novo" para o samba e também para sua comunidade, provocador de curto-circuito nas relações já desgastadas entre ambos pela apropriação branca do samba via bossa nova. $\mathrm{O}$ retorno ao maracatu é sintomático, sendo este um gênero então bastante ligado a suas fontes populares e ignorado pelos setores dominantes. De maneira geral, 
nesse diálogo, o álbum apresenta-se como expressivamente mais rítmico, mais dançável, menos delicado, menos lírico e menos rico em suas letras, menos rico harmonicamente, mais "popular" do que a bossa nova, ao menos segundo os parâmetros do período em que se insere. Percebe-se aí a característica da circularidade (cf. Burke, 1989) da cultura popular. Artistas das classes subalternas, como Jorge Ben, buscaram apropriar-se também de certos elementos atribuídos à elite, entre eles as conquistas técnicas da BN. Apesar disso, essa apropriação deixaria marcas de classe, subvertendo o gênero elitizado naquilo que seria mais caro às elites: noções burguesas de "bom gosto" e "sutileza".

Esse primeiro LP representou um fato novo na época e, dois meses após seu lançamento, havia vendido 100 mil cópias, estabelecendo uma marca de popularidade que evidencia a participação do coletivo anônimo na definição da nascente MPB.

Por outro lado, tendo lançado seu primeiro LP em 1961, Elis Regina dedicava-se até 1963 exclusivamente a gêneros comerciais sem referências políticas: músicas românticas, para adolescentes e adultos, e o samba-canção de corte antigo, abolerado ou não, passando pela balada pop e ritmos caribenhos.

Ellis Regina conteria o primeiro samba marcado a ser gravado pela cantora, "Silêncio" (Tulio Paiva). É nessa gravação que ela começa a encontrar sua voz individual. Elis ousa sair da marcação cométrica (ou seja, "quadrada") das músicas românticas e juvenis, com sentido convencional de recato, restrição sexual, para seguir um código cultural reificador e exoticizante firmemente implantado. Ao se deslocar ao longo desses eixos em direção ao ponto em que se cruzavam "suíngue" e erotismo, Elis descartou toda uma imagem comercial/artística e entrou em uma outra, ambas mutuamente excludentes. E essa imagem, mais uma vez, era indicada por seu público, cujo traço podemos perceber na performance.

Logo no início de "Silêncio", por meio de um improviso retirado do refrão, Elis explicitamente chama a atenção do ouvinte para o ritmo, brincando com ambos: "O samba já tem outra marcação/ E essa é a nova marcação/ Olha só". Explicitava, assim, seu envolvimento na busca de um novo caminho artístico-comercial para o samba, sua vontade de atingir os desejos do público.

Como vimos, 1963, o ano do lançamento desse álbum, foi o ano em que Jorge Ben lançou seu Samba esquema novo, e pode-se pensar aí numa disputa para ver quem conseguia impor um estilo pessoal capaz de se tornar um gênero. No entanto, enquanto Jorge Ben realmente tinha algo novo a propor, a "nova marcação" de Elis se resumia a um retorno ao velho samba, inclusive em termos de instrumentação. O que ambos os álbuns têm em comum, no entanto, é seu visível apelo e subordinação às expectativas do público quanto às imagens sonoras nas quais este desejava ver-se refletido. 
Certamente não se pode falar aqui de um projeto nacional-popular, pois todos esses álbuns iniciais são inteiramente alheios a discussões políticas ou ideológicas. $\mathrm{O}$ que emerge da audição desses discos antigos é simplesmente a disputa pelo sucesso e popularidade. Eles tornam evidente que grandes contingentes da população desejavam ver-se representados em gêneros musicais diferentes da $\mathrm{BN}$, e seria esse dado que conformaria a nascente MPB. Como ninguém sabia exatamente onde queria chegar, a história da MPB reveste-se assim do caráter de uma experimentação constante, constituindo um processo complexo de tentativa e erro de descoberta dos desejos de identidades sonoras coletivas. Essa versão se contrapõe às narrativas heroicas das "revoluções" musicais, enquanto resultados intuídos a priori por subjetividades colocadas acima do processo histórico - fossem de compositores, grupos ideológicos ou agentes da indústria cultural.

Existe algo eminentemente transgressor em Jorge Ben, que está ligado, provavelmente, ao seu ritmo, e às maneiras que ele encontra para comunicar as ideias de negritude e de África de forma excitante a seus admiradores. Como disse Caetano Veloso, "Jorge Ben era não apenas o primeiro grande autor negro desde a bossa nova ... mas era principalmente também o primeiro a fazer desse fato uma determinante estilística" (Veloso, 1997: 197). Apesar dessa opinião disseminada, virtualmente não se conhecem análises que demonstrem precisamente como influências negro-africanas se inserem na obra de Jorge Ben (ver, a respeito, Neder, 2007).

Ser filho e neto de etíopes produziria fortes identificações com a África, conforme tornava explícito o próprio compositor em entrevista originalmente publicada na Revista do Rádio de 28 de setembro de 1963: "Meu avô, que era etíope, chamava-se Ben Jorge. Em homenagem a ele, inverti o nome e passei a chamar-me, artisticamente, Jorge Ben... Meu grande sonho foi sempre o de conhecer a Etiópia, terra dos meus avós" (apud Sampaio [1963], 2006). Ao vincular-se à ancestralidade africana, Jorge Ben separava-se assim, desde o princípio, da ideologia mulata preconizada por Gilberto Freyre.

É fundamental ressaltar, nesse e em outros álbuns de Jorge Ben, as influências afro-estadunidenses do rock, soul, blues e gospel e as referências a um imaginário negro-africano. Todos esses novos estilos e gêneros que se notam na nascente MPB a partir de Jorge Ben indicam não uma formação discursiva alinhada às classes dominantes, como a $\mathrm{BN}$, mas a participação social de comunidades subalternas, objetivada em discursos musicais associados a outras práticas, estas marginais. Ao invés de limitar-se a uma expressão nacionalista de segmentos universitários, a MPB circunscreve um espaço de intensos conflitos, o encontro entre o popular e o erudito, o alto e o baixo, o cosmopolita e o regional, o dominante e o dominado. 
Samba esquema novo possui vários indícios do samba-rock que viria a ser lançado por Jorge Ben ainda naquela década. Entre eles, a batida (que se encaixa perfeitamente na métrica do samba-maracatu) e o falsete.

O falsete é um dos aspectos enigmáticos da música de Jorge Ben e que merecem maior atenção. Jorge Ben foi talvez o primeiro intérprete na música popular brasileira a fazer do falsete, mais do que uma ocorrência ocasional, praticamente um elemento definidor de seu estilo inicial. Para buscarmos compreender o motivo dessa importância, devemos saber que o falsete é um elemento africano tradicional. Entretanto, Jorge Ben não tomou o falsete diretamente da tradição africana, e sim da música negra estadunidense em que se misturara. O chamado falsetto wail ou falsetto leap é abundante nos gêneros negros como ofunk, gospel e outras músicas populares, introduzidos na cultura estadunidense desde os primeiros tempos da escravidão africana naquele país, por meio dos cantos de trabalho nas lavouras (field holler) (Russel, 2001: 194).

Assim como outros efeitos vocais herdados da tradição africana, que hoje fazem parte dos gêneros musicais populares modernos em todas as Américas e no Caribe - guturalidade, vocalidade interpolada, "blue notes", afro-melismas, improvisações com as letras, transformação da voz em instrumento rítmico -, o falsete ajuda a construir um espaço preenchido por significações identitárias africanas. Esse espaço imaginário ancestral engloba diversas formas de sociabilidade, expressando da sexualidade ao sagrado, e tornando-se, assim, o espaço ritual da tradição africana, "máscaras falando por meio de vozes em falsete para representar os deuses" (Akpabot, 1977: 3).

Entrecruzam-se, assim, as relações entre referências identitárias africanas, gêneros populares estadunidenses produzidos no âmbito da diáspora atlântica e a música de Jorge Ben como contestação à hegemonia da ideologia mestiça no Brasil. Com base nesse primeiro álbum de Jorge Ben, precursor do samba-rock que viria a ser lançado pelo compositor logo depois, é curioso que os relatos canônicos sobre a MPB sustentem que o rock e o pop estadunidense tenham sido rejeitados por toda a MPB. Foi através desse tipo de generalização que se instituiu a crença de que a MPB se define pelo alinhamento ao projeto nacional-popular, em vez de se perceber neste apenas um dos vetores ideológicos que atravessam a MPB.

Ainda outro desses vetores é colocado pela atividade das mulheres na MPB, como Nara Leão, que, certamente, possui características próprias, não redutíveis às preocupações nacionalistas e de esquerda.

Nara foi uma pessoa intrigante. Dos 14 aos 19 anos viveu intensamente a $\mathrm{BN}$, tornando-se a "musa" do movimento. Abandonou-o para gravar músicas "regionais" e "politizadas", segundo a narrativa canônica, que diminui o papel de importantes compositores que recuperou, como Cartola, Nelson Cavaquinho e Zé Kéti. Na verdade, ao invés de se fixar em movimentos - como a BN ou o na- 
cional-popular - Nara foi uma cantora extremamente eclética, como ela mesmo declarou:

O fato de apoiar todos os movimentos, desde que fossem bons, fez com que eu reunisse o maior repertório do Brasil. As pessoas podem ter discutido se eu canto ou não canto, se gostam ou não gostam, mas têm que admitir que a minha falta de preconceito em relação aos movimentos fez com que eu gravasse coisas antigas, novas e de vanguarda. (apud Távola, 2006)

Essa busca de controle sobre sua produção, aliada à sua independência com relação às expectativas dos líderes de movimentos e do público, pode ser entendida como um questionamento ao lugar ocupado pela mulher na cadeia produtiva da indústria da música e mesmo na sociedade.

Isso fica mais evidente a partir de sua recusa à posição estagnada de "musa" da BN, descrita dessa maneira até mesmo por Ruy Castro:

[e]nquanto cantava nos apartamentos e shows universitários da Bossa Nova, ninguém ligava muito para Nara Leão. Ela era, no máximo, um bibelô querido por todos - Menescal, Lyra e, claro, seu noivo Ronaldo Bôscoli. Quando a turminha começou a se profissionalizar, no final de 1960, eles próprios se encarregaram de impedir que Nara fizesse o mesmo. Tinha de continuar no papel de musa. ... achavam que, pela sua estrutura frágil como uma libélula, Nara não deveria se meter na guerra sem escrúpulos do meio profissional. E ... os preconceitos eram tão belle époque que, para eles, ela não era do tipo que deveria cantar "na noite". (Castro, 1990: 343-4)

Evidentemente, a idéia de "proteção" disfarça mal um sentimento de dominação. Estabelecer a cantora em uma posição idealizada de musa (o que encontra ressonâncias em toda a história do feminino, mais visível na tradição católica de adoração da Virgem) parece evidenciar uma maneira de estabelecer uma relação de poder com ela. Negando-se a considerá-la uma igual e designando-lhe um lugar predeterminado, aparentemente lisonjeiro e inofensivo, seus colegas de movimento evitavam assim a competição e a situação que acabou se impondo, com o estrondoso sucesso popular alcançado pela cantora.

A preocupação com sua posição como representante do universo feminino é mais evidenciada por sua gravação - a primeira, aliás - de "Maria Moita" 
(Carlos Lyra e Vinicius de Moraes). De conteúdo feminista, a letra fala da exploração da mulher pelo homem, independentemente da classe social: "Meu pai dormia em cama/ Minha mãe no pisador/ Meu pai só dizia assim, venha cá/ Minha mãe dizia sim, sem falar/Mulher que fala muito perde logo seu amor/ Deus fez primeiro o homem/ A mulher nasceu depois/ Por isso é que a mulher/ Trabalha sempre pelos dois/Homem acaba de chegar, tá com fome/ A mulher tem que olhar pelo homem/ E é deitada, em pé, mulher tem é que trabalhar".

Já não "musa da bossa nova", Nara também não desejava se deixar aprisionar à expectativa daqueles que a queriam "musa do protesto" - mais uma categoria dominada por homens. Isso fica evidente em sua reprovação a um dos momentos mais lembrados pelos críticos do nacional-popular como representativo da intolerância de seus membros, que ficou conhecido como "a passeata contra a guitarra elétrica". Divulgado como a passeata da "Frente Ampla da MPB contra o Iê-Iê-Iê", o episódio, ocorrido em 1967, é explicado por Caetano Veloso como "ridícula e perigosa jogada de marketing" da TV Record para lançar um novo programa que viria a ter o nome de Frente Ampla da MPB. Segundo o depoimento de Caetano, "Nara e eu assistimos, assombrados, de uma janela do Hotel Danúbio, à passagem da sinistra procissão. Lembro que ela comentou: 'Isso mete até medo. Parece uma passeata do Partido Integralista"' (Veloso, 1997: 161).

Nara não se limitou às músicas da BN (que voltou a gravar em 1971), do Opinião ou da Tropicália. Iniciou o processo de retomada do samba, recuperou importantes choros e tangos antigos como "Odeon" e "Apanhei-te, cavaquinho" (de Ernesto Nazareth), e em 1978 gravou o álbum E que tudo o mais vá pro inferno, inteiramente dedicado às músicas de Erasmo Carlos e Roberto Carlos. Nas palavras de seu ex-marido Cacá Diegues, seu ecletismo singular se acentuou:

Foi ela quem descobriu o grupo baiano no Teatro Vila Velha, de Salvador, e trouxe Maria Bethânia para o show Opinião, no Rio de Janeiro, ... quem primeiro gravou Edu Lobo, Chico Buarque, Caetano Veloso, Sidney Miller ... quem trouxe de volta à música popular brasileira os compositores de morros cariocas ... quem primeiro reintegrou Carmem Miranda à tradição nacional ... ainda nos anos $60, \ldots$ quem primeiro avalizou os tropicalistas, quando estes ainda eram rejeitados ... (apud Távola, 2006)

A independência de Nara Leão, compreendida como signo de insubordinação feminina ao aprisionamento nas categorias dominadas por homens em disputa por poder político e econômico no palco da cultura brasileira dos anos 1960 e além, adiciona outra camada de sentido à MPB inicial. 
Da mesma maneira que as questões propostas pelas mulheres na MPB inicial não são evidenciadas pela narrativa hegemônica, a insistência em vincular esse movimento aos universitários de esquerda vem dificultan do a percepção da atividade do coletivo anônimo sobre a construção desse movimento musical. Já em 1964, pode-se perceber tal popularização produzindo um novo fenômeno de massificação do público nos shows O Fino da Bossa e Opinião. E a TV logo se faria notar também nessa aproximação, com o lançamento dos programas musicais O Fino da Bossa (maio de 1965), Bossaudade, com Elizete Cardoso e Ciro Monteiro (julho de 1965), efovem Guarda (setembro de 1965), com Roberto Carlos, Erasmo Carlos e Wanderléa, todos líderes de audiência. Conforme diz Napolitano:

A relação música e TV nos anos 60 ... tornou fluidas as fronteiras entre as faixas de consumidores, ampliando a audiência no nível quantitativo e alterando sua composição qualitativa. Se é plausível afirmar que a TV era um veículo da e para a classe média, essa categoria sociológica era muito ampla para fornecer alguma explicação mais precisa sobre as consequências do consumo musical. (Napolitano, 2001: 80)

Ou seja, a TV, em geral entendida como veículo da e para a classe média naquele momento introdutório, abria-se, na verdade, à atividade da sociedade como um todo, tornada pouco visível em um momento em que o mercado incipiente se encontrava pouco segmentado. Nesse panorama de crescente predomínio dos setores subalternos, os estudantes universitários perdem sua primazia na determinação das identidades a serem veiculadas nas canções e gêneros:

O circuito universitário, secundado pela boêmia mais sofisticada, que ainda tinha uma certa homologia com o circuito de shows profissionais direcionados aos jovens e intelectuais (como Opinião e Arena conta Zumbi, entre outros), é deslocado, perdendo o papel que tinha de centro gerador do mercado musical brasileiro. A TV representou não só uma ampliação da faixa etária consumidora de MPB renovada ..., mas uma ampliação de audiência da MPB em todas as faixas sociais, na medida em que a TV era um fenômeno de segmentos médios bem amplos: as classes $\mathrm{B}$ e $\mathrm{C}$ (que poderiam ser traduzidas como classe média alta e baixa, ainda sem os desníveis de cultura e renda atuais) detinham cerca de 70\% dos aparelhos de televisão em São Paulo. (Napolitano, 2001: 80) 
$\mathrm{O}$ antigo público do rádio, vinculado à música popular tradicional pré-BN, migrava para a televisão. Tanto nas personalidades artísticas dos ídolos do momento - Elis Regina, Chico Buarque e Roberto Carlos, por exemplo quanto na estética e no tom das apresentações (a gala, a impostação, a formalidade), em tudo havia uma forte impregnação das expectativas tradicionais populares. Os festivais, com seu histrionismo, seu enorme apelo popular, seu aspecto extrovertido e esfuziante, são indicações determinantes das comunidades mais amplas como sustentação e razão de ser do novo estilo que surgia.

O show Dois na Bossa, com Elis Regina e Jair Rodrigues, lançado com grande sucesso popular em 1965, é um marco nesse processo de manifestação subliminar do coletivo. Segundo Paulo César de Araújo, "[1]ançado pela Philips em maio de 1965, aquele LP bateu todos os recordes de vendagem, atingindo a cifra de 500 mil cópias. Nunca até então um LP tinha vendido tanto no Brasil" (Araújo, 2006: 212). O espírito esfuziante da dupla e a linguagem cênica e musical de ambos eram francamente populares, e sua comunicabilidade com as plateias foi sempre assinalada. Essa linguagem ligava-se às expectativas populares do rádio e do teatro tradicional (que vinha desenvolvendo a fórmula de música e alegria desde os espetáculos de entremezes, já existentes no Brasil no século XVIII).

No entanto, a TV simultaneamente encorajava a experimentação com as linguagens “jovens”, ou seja, o rock e a Jovem Guarda. Chegando ao mercado em novembro de 1965, o LP Fovem Guarda, de Roberto Carlos, trouxe o hit "Quero que vá tudo pro inferno" (Roberto Carlos/ Erasmo Carlos). A recepção dessa música evidenciou o impacto que o rock exerceu sobre diferentes grupos ideológicos:

"Quero que vá tudo pro inferno foi o fenômeno de massa mais intenso que eu vi na minha geração", afirma Caetano Veloso... Muitos ainda se lembram ... o que sentiram ao ouvi-la pela primeira vez ... [, como] a cantora Fafá de Belém ... "Falei na hora: Humm, como esse cara é moderno". Outro ... é ... Alceu Valença ... "achei aquilo uma coisa muito forte e bonita." ... Djavan ... "Foi um impacto, fiquei muito empolgado" ... Raimundo Fagner: ..."logo depois de ouvir essa música ... estava tocando porque ... todos cantavam juntos, em coro"... Para Zé Ramalho, a música se confundia com o cenário de repressão pós-golpe militar que na época ele ainda não compreendia direito. "Eu me lembro de ver a polícia correndo atrás de estudantes na rua, carros revirados, ônibus incendiados, e Quero que vá tudo pro inferno tocando no rádio. Era um cenário louco, um apocalipse danado... Luiz Melodia: "Foi uma febre no morro. A gente ouvia a música o dia inteiro.” ... [N]a época a cantora 
Nana Caymmi estava morando em Caracas ... "Quero que vá tudo pro inferno foi um estouro na Venezuela. ... Irreverente como sou, adoro aquela letra”. (Fróes, 2000: 169-70)

Desejo apontar aqui para a possibilidade de que muitos daqueles que se acredita serem naturalmente opostos à JG por serem oriundos de uma classe média "estudantil" e "de esquerda" pudessem identificar-se com a JG por esta estar a proporcionar algo que desejassem. Essa situação, que torna indistinta a JG da $\mathrm{MPB}$, fazendo perceber, do ponto de vista da recepção, que talvez as segmentações de mercado na década de 1960 não estivessem funcionando da forma ordeira que se acredita, é subsidiada pelo levantamento realizado por Marcos Napolitano:

Num momento de reorganização do mercado de bens culturais, como o que estava se processando naquele período, os públicos consumidores podem não estar rigidamente delimitados. Portanto, a disputa entre MPB e jovem guarda tinha um certo sentido: ambas disputavam franjas de público que se tocavam ..., segmentos difusos, sociologicamente falando, que gravitavam em torno da nova mídia televisiva ... O público mais adulto transitava pelos dois estilos de forma mais fluida, como demonstram as audiências televisivas dos dois programas. (Napolitano, 2001: 99-101)

Celebrada como a maior estrela da música popular brasileira em 1965, Elis Regina saiu de férias em dezembro para uma viagem à Europa. Nesse meio tempo aconteceu “Quero que vá tudo pro inferno". Na volta de Elis, em março de 1966, o cantor em evidência passara a ser Roberto Carlos, o disco mais vendido Quero que vá tudo pro inferno, e o musical de maior audiência era o fovem Guarda (Araújo, 2006: 213). A reação da cantora demonstrou sua incredulidade com o aumento da popularidade da JG, e seu irritado desabafo (reproduzido em Fróes, 2000: 89) evidenciava perplexidade e insegurança quanto a seu futuro. Motivadas por esse sentimento de ameaça, seguiram-se as expulsões de Jorge Ben, Wilson Simonal e Claudette Soares do Fino da Bossa por suas participações no fovem Guarda (Araújo, 2006: 228).

Estes fatos levaram à arraigada noção de que a JG era popular, enquanto a MPB era ouvida por uma pequena minoria de estudantes de esquerda e intelectuais. Mas, na verdade, o que ocorreu foi o oposto. Após um intenso e curto surto de sucesso, a JG viu-se forçada a buscar seu público de volta das "hostes" da MPB por meio da tentativa de desenvolver um tipo de samba que lhe permitisse sobreviver: 
... Erasmo Carlos juntou-se com Pery Ribeiro, Wilson Simonal, Bossa Três, Carlos Imperial e Jorge Ben, na criação de um novo ritmo: o chamado "samba jovem", que misturava iê iê iê e bossa nova numa batida espetacular. ... Erasmo dava uma definição da novidade: "Usando na bateria a batida do samba, e utilizando guitarras com marcação do iê iê iê, o novo ritmo é dinâmico, moderno e acessível... Não sei o que os críticos musicais vão dizer do samba jovem, mas é um esforço nosso para divulgar o samba." (Fróes, 2000: 90)

Como vimos, Jorge Ben já vinha desde muito antes envolvido na pesquisa de sua própria fórmula de "samba jovem". Outros desse grupo, como Simonal e Imperial, já vinham trabalhando com suas buscas de uma linguagem "jovem" para o samba, vindo a constituir a Turma da Pilantragem, com sua fusão de samba e soul music. "Mamãe passou açúcar em mim", lançada por Simonal nesse período, seria o início desta outra vertente de samba. Erasmo, Roberto e Ronnie Von fariam experiências e tentativas frustradas de se aproximar do imaginário da MPB a partir de 1967, quando a JG já estava visivelmente se esvaziando em termos de popularidade (o programa deixou de existir no início de 1968).

Esses fatos evidenciam a ausência de uma segmentação radical entre o rock e a MPB nos anos 1960. Ao contrário, verifica-se que houve considerável superposição de gostos entre os diferentes públicos. O mesmo continuaria existindo com a entrada da Tropicália em cena em 1967, o que causou o declínio da JG. Que o público da JG era também o público da MPB é afirmado pelo fato de que os artistas da JG perceberam a queda de popularidade do gênero e buscaram trazer sua audiência de volta disputando-a com a MPB, assumindo suas características. Napolitano chegou às mesmas conclusões, como se pode ver:

... em 1967 a situação se inverte, pois quem vai disputar o público da canção engajada é a Jovem Guarda. ... é muito estranho o fato de que no Festival da TV Record, de 67, os cantores da Jovem Guarda vão ocupar a cena do festival com canções engajadas, ou pelo menos uma tentativa de. Roberto Carlos, por exemplo, com "Maria, carnaval e cinzas". Nesta letra, Roberto Carlos fala de uma pessoa que vive um carnaval, que mora numa favela, a Maria. Maria era uma figura simbólica das canções engajadas, a mulher do povo. ... O Ronnie Von, o Príncipe, cantou uma música chamada "Minha gente", que também foi uma tentativa de fazer uma coisa mais exortativa. O Erasmo Carlos fez algo parecido com um afro-samba, chamado "Capoeirada". Era todo o imaginário da MPB numa tentativa de releitura, de revisão. Na verdade, a Jovem 
Guarda estava em crise no mercado fonográfico, tanto que o programa acabou no início de 68. Roberto Carlos percebeu que a canoa estava fazendo água e saiu fora. Acabou construindo uma carreira extremamente sólida, mas o pessoal da Jovem Guarda perdeu o rumo. ... Do ponto de vista, entretanto, do mercado fonográfico, eles saíram de cena enquanto a MPB ocupou o lugar central ... (Napolitano, 2003: 131-2)

"Para onde" teria ido o público da JG que abandonava o programa e os lançamentos do gênero? A busca dos gêneros tradicionais por parte dos artistas do iê-iê-iê nos dão uma pista (a música "em si” nos ajuda a perceber uma história difícil de ser contada de outra maneira). Efetivamente, por volta de agosto de 1967, seguindo a deixa de Nara Leão, de trazer para a MPB nomes tradicionais como Cartola e Nelson Cavaquinho, Roberto Carlos buscava diminuir a distância entre a JG e a MPB e injetar interesse no fovem Guarda com outro importante sambista do passado, então no ostracismo: Ataulfo Alves.

Ataulfo compareceu ao programa, numa bela tarde de domingo, e cada qual cantou uma música do outro. No final, ambos cantaram juntos o eterno sucesso "Ai que saudades da Amélia". Semanas depois, para surpresa de muitos, Roberto Carlos entrou no estúdio e gravou esse samba, que tem a mesma idade que ele. ... Mas a boa relação de Ataulfo Alves com a jovem guarda não pararia por aí. Agradecido pelo empenho de Carlos Imperial nesse seu processo de redescoberta pelo público jovem, Ataulfo estreitou relações com ele e juntos fizeram o samba "Você passa e eu acho graça", que se tornaria o primeiro sucesso da cantora Clara Nunes, em 1968. (Araújo, 2006: 240-1)

No ano seguinte, deu-se a grande inversão de papéis: a MPB, no recinto dos festivais, antes ciosamente fechado ao rock e às guitarras, escancarou suas portas a ambos. E Roberto Carlos despediu-se do fovem Guarda, abraçando sua nova carreira romântica - portanto, mais próxima dos públicos tradicionais que também constituíram a MPB. Essa permutabilidade só seria possível se diferentes faixas de público já se estivessem misturando em todos esses estilos antes daquele momento.

O ano de 1968 foi explosivo... [No festival daquele ano] houve uma diversidade maior de gêneros musicais, rompendo a hegemonia de sambas e marchas... das dezoito músicas apresentadas na pri- 
meira eliminatória, pelo menos dez traziam guitarras elétricas em seus arranjos. A inesperada profusão de plugues e cabos elétricos chegou a provocar problemas técnicos no palco do Teatro Paramount. Em alguns momentos, as tomadas disponíveis não foram suficientes para conectar todos os fios. Os tropicalistas pareciam ter arrombado a porta da MPB para a entrada do que antes era privilégio apenas de Roberto Carlos e da turma da jovem guarda. (Araújo, 2006: 248)

Como fatos geradores de mobilização sem precedentes na cultura nacional, os festivais apresentaram atrativos em torno da MPB que foram fortes o bastante para demonstrar ao público que poderia dar a ele tudo o que desejava, inclusive os novos comportamentos mediados pelo rock. Por conta disso, tanto Napolitano como Araújo concordam com o questionamento da narrativa de que a Tropicália houvesse contrariado as expectativas do público majoritário:

Como bem aponta o historiador Marcos Napolitano, a mística posterior criada em torno do tropicalismo superdimensionou o ato de ruptura de Caetano e Gil com o código vigente da MPB. Para essa afirmação do tropicalismo como vanguarda heróica contribuíram principalmente dois mitos: que as estruturas de festival rejeitaram o movimento e que eles foram os alvos preferenciais das vaias da plateia. Vejam-se os casos, por exemplo, de Alegria, alegria e Domingo no parque no festival da Record de 1967. Ambas entraram para a mitologia dos festivais como um momento de confronto com as preferências da plateia estudantil e de esquerda. Entretanto, não houve grandes vaias nem para Caetano Veloso nem para Gilberto Gil naquele festival. Ao contrário, ambos foram aplaudidos nas suas apresentações. No dia da final, Caetano Veloso foi recebido com aplausos, flores e sob uma gritaria generalizada de "Já ganhou!". O público tinha decorado a letra da música e cantou junto com ele, gritando ao final: "Primeiro! Primeiro!". Foram tantos os pedidos que Caetano Veloso teve de bisar sua música. As vaias mais fortes foram direcionadas ao júri quando foi anunciado que Alegria, alegria tinha ficado em quarto lugar. $O$ público queria uma melhor colocação para a música de Caetano Veloso. Na apresentação final de Domingo no parque, a mesma coisa: aplausos para Gil e Os Mutantes e gritos de "Já ganhou!" (Araújo, 2006: 257-8)

Confirmando a tese aqui defendida, de que os grupos sociais brasileiros mais amplos desejavam o rock, mas encontravam obstáculos para celebrá-lo no 
âmbito da MPB devido à atuação de grupos nacionalistas localizados nas cúpulas das organizações formuladoras de políticas gerais e culturais, e de músicos e performers interessados em manter seu mercado, conclui Araújo:

O tropicalismo sofreu rejeição de setores radicais e minoritários no interior da própria MPB - não das chamadas estruturas ou da plateia jovem universitária. Tanto que, depois do festival, teve um sucesso rápido e intenso. Caetano Veloso tornou-se um pop star, e Alegria, alegria um hit, tocada intensamente nas rádios. (Araújo, 2006: 258)

As mesmas conclusões foram obtidas nas entrevistas realizadas com a hoje professora Ana Maria de Moura Nogueira (Nogueira, 2005), no âmbito de uma etnografia sobre a MPB realizada por mim (Neder, 2007). Como membro de movimentos políticos estudantis e universitários associados à extrema esquerda, estudante secundarista nos anos 1960 e acadêmica de História nos anos 1970, Ana Maria foi fiel o bastante a seus ideais nacionalistas e esquerdistas para deixar-se prender pela ditadura militar devido a tais associações.

Como se sabe, no contexto fortemente polarizado dos anos 1960 a política estudantil de esquerda estava sempre pronta a recalcar questionamentos existenciais e estéticos sob rótulos pejorativos como "burguês", "alienado" e "americanizado". Nesse sentido, o depoimento de Ana Maria proporciona evidências para a reivindicação aqui apresentada, de que mesmo pessoas que estavam profundamente envolvidas em uma luta nacionalista e esquerdista identificaram-se com os desejos transnacionais da juventude daquele período, mesmo sob pena de serem expostas às críticas e segregações do grupo. Esses desejos envolveram questões existenciais de sexo, autoridade, liberdade e também questões estéticas como a música (rock) e a moda. E a música foi um fator central naquela poderosa desestabilização de uma identidade fixa, de acordo com Ana Maria:

As pessoas com quem eu me dava eram muito rígidas, eram dos grupos AP, PC do B, e elas achavam músicas do Chico, como "Sabiá," "Carolina," totalmente alienadas. Eu fiquei bem dividida, principalmente mais tarde quando apareceram Caetano e Gil. Isso colocou em questão nossas formas de pensar sobre o que era fazer protesto, formas de se opor à sociedade que não eram aquelas ortodoxas, que eram os modelos que a gente seguia de outras revoluções, de outras situações. ... "Domingo no Parque," "Alegria, Alegria" [canções tropicalistas] expandiram as maneiras de exprimir a insatisfação. De repente, não era só 
movimento operário, não era só política ortodoxa de esquerda, mas uma manifestação de protesto generalizado, inclusive estética. Os tropicalistas bagunçaram nossa avaliação sobre o que era ser revolucionário. Nós criticamos as diretrizes ortodoxas, mas outros não o fizeram, e houve inclusive rompimentos de amizades, além de vínculos de ação política por causa disso. (Nogueira, 2005)

Os sentimentos despertados pela música nem sempre eram compatíveis com as ideologias dos partidos nacionalistas. A versão de Ana Maria a respeito da comoção nacional que cercou o III Festival Internacional da Canção (1968) na disputa entre "Sabiá" (de Chico Buarque e Antonio Carlos Jobim) e "Pra Não Dizer que Não Falei das Flores" (canção de protesto de Geraldo Vandré) é esclarecedora nesse sentido:

a pressão do grupo era enorme, a gente tinha que torcer pelo Vandré, mas eu sempre preferi o Chico ao Vandré. O que é um momento revolucionário: faz as pessoas entrarem numa radicalização braba mesmo. "Caminhando" (Vandré) refletia tudo aquilo, a gente chorava ouvindo a música. (Nogueira, 2005)

Um dos partidos mais radicais da época, o PC do B, que é tido pelos críticos do nacionalismo de esquerda como totalmente fechado à diferença, é retratado no depoimento de Ana Maria como muito menos monolítico e mais aberto à discussão:

A gente participava ativamente das discussões sobre música, depois dos festivais tinha conversas, era uma coisa muito forte. Os festivais eram outro foco de discórdia. Por um lado eram uma coisa burguesa, eram patrocinados [por empresas capitalistas] etc. Por outro lado, davam voz a essas músicas e nós achávamos o máximo. O PC do B criou o espaço da discussão política sobre essas questões culturais, musicais, sobre quem deveríamos apoiar, e isso foi muito bom. (Nogueira, 2005)

Ao mesmo tempo, ao confessar-se "envergonhada" de sua identificação com música e comportamentos "burgueses", ela testemunha a importância dessa música que a levou a transgredir as regras do partido mesmo sob pena de ser reprimida pelos companheiros. 
Eu gostava da música dos Tropicalistas, das músicas consideradas "alienadas," e tinha muita vergonha. Mas isso não me impedia de ouvir e gostar da música. Eu comprava os discos, tinha todos os discos e ouvia em casa [com os companheiros que pensavam como eu]. (Nogueira, 2005)

Uma parte muito importante do depoimento de Ana Maria é a que se segue, em que ela fala sobre a relação direta do PC do B com Gilberto Gil, opositor do nacionalismo e da esquerda tradicional/ radical. O trecho seguinte contradiz as noções prevalentes que tentam retratar organizações radicais como o PC do B como sendo homogeneamente e univocamente opostas aos artistas que não estivessem envolvidos com suas ideologias:

Minha primeira missão dentro do $\mathrm{PC}$ do $\mathrm{B}$ foi a de ir à Bahia e contatar o Gilberto Gil para pedir apoio para recolher fundos que seriam para ajudar os companheiros que estavam presos. E ele numa boa. Veio e fez o maior showzaço na PUC do Rio. (Nogueira, 2005)

É interessante notar o efeito dessas contradições na reafirmação de identidades divididas. Como a de Ana Maria, uma estudante de esquerda da década de 1960 que contribui para desautorizar o modelo esquemático perenizado pela narrativa canônica ao evidenciar que a participação da música popular na construção da subjetividade e da história dos anos 1960 era muito mais complexa.

Isso se explica nos termos de uma política da identidade. À medida que a década de 1960 avançava, e antes que alguns desses movimentos sociais estivessem objetivamente articulados no Brasil, notícias chegavam sobre novas posições subjetivas disponíveis para mulheres, negros, operários, ecologistas, jovens, homossexuais ou mesmo para todas as pessoas sem distinção. Nesse contexto torna-se problemático afirmar que, mesmo assim, o grupo definido em abstrato como "os estudantes" se tenha mantido tão coeso em torno de uma bandeira unitária como em geral se pensa. Se faz algum sentido pensar em um quadro mais complexo, talvez então seja produtivo começar a desenvolver a imagem de um coletivo unido por determinados pontos em comum, que manifestava sua concordância em relação a certas tarefas principais que possuíam uma visibilidade maior.

No entanto, acredito que a essas questões mais visíveis se superpunham outras preocupações e desejos, tornando essa significação aparentemente unívoca na verdade altamente complexa, compósita e polissêmica. Nos interstícios, nas lacunas, nas falhas, nas práticas alternativas, nos tecidos de solidariedade va- 
riamente motivada seriam inscritas outras identidades, organizadas outras narrativas, estabelecidas outras alianças. Vínculos familiares, associações com grupos de amigos de infância, hábitos de lazer, práticas religiosas e devocionais, o mosaico fragmentário da vida em uma sociedade complexa é um permanente convite à dispersão, à organização de redes alternativas de socialidade, que trazem obstáculos à estabilidade, continuidade e coesão de ideologias e de uma identidade estável. De certa maneira, o discurso político militante teria, assim, servido de bandeira comum de luta a um vasto universo de pessoas que na verdade sincretizariam desse modo um quadro de desejos e identidades sensivelmente mais amplo e multifacetado.

Como terreno contraditório em que esses conflitos foram encenados, a MPB dos anos 1960 se apresenta como espaço disputado, sempre em movimento, nunca estabilizado pela dominância final de um grupo social ou ideológico. Justamente por isso, foi tão importante para a expressão de ideários políticos e desejos subjetivos naquele momento, e continua sendo fundamental para a compreensão da história do Brasil.

\section{Referências bibliográficas}

AKPABOT, S. Anthropology of African music. In: Africa: Journal of the International African Institute, v.47, $\mathrm{n}^{\circ} 2$, Supplement: IAI Bulletin 1977: 2-3.

ARAÚJO, Paulo Cesar de. Roberto Carlos em detalhes. São Paulo: Editora Planeta, 2006.

BURKE, Peter. Cultura popular na Idade Moderna. Europa, 1500-1800. $2^{\text {a }}$ ed. São Paulo: Companhia das Letras, 1989.

CAMPOS, Augusto de. Balanço da bossa e outras bossas. $2^{\mathrm{a}}$ ed. São Paulo: Perspectiva, 1974a.

—. Da Jovem Guarda a João Gilberto. In: - Balanço da bossa e outras bossas. $2^{\mathrm{a}}$ ed. São Paulo: Perspectiva, 1974b.

O passo à frente de Caetano Veloso e Gilberto Gil. In: —. Balanço da bossa e outras bossas. $2^{\mathrm{a}}$ ed. São Paulo: Perspectiva, 1974c.

CASTRO, Ruy. Chega de saudade: a história e as histórias da bossa nova. São Paulo: Companhia das Letras, 1990.

CONTIER, Arnaldo. Edu Lobo e Carlos Lyra: o nacional e o popular na canção de protesto. Revista Brasileira de História, v.18, $\mathrm{n}^{\circ}$ 35, ANPUH/Humanitas, 1998: 13-52.

FRÓES, Marcelo. Fovem Guarda: em ritmo de aventura. São Paulo: 34, 2000.

NAPOLITANO, Marcos. A canção engajada nos anos 60. In: DUARTE, Paulo Sergio e NAVES, Santuza Cambraia (orgs.). Do samba-canção à Tropicália. Rio de Janeiro: Faperj/Relume-Dumará, 2003. 
- Seguindo a canção: engajamento político e indústria cultural na $\mathrm{MPB}$ 1959/1969. São Paulo: Anna Blume/FAPESP, 2001.

NEDER, Alvaro. O enigma da MPB e a trama das vozes: identidade e intertextualidade no discurso musical dos anos 60. Tese de doutorado em Letras - Departamento de Letras, Pontifícia Universidade Católica do Rio de Janeiro, 2007.

NOGUEIRA, Ana Maria de Moura. Depoimento ao autor, 2005.

ROCHA BRITO, Brasil. Bossa nova. In: CAMPOS, Augusto de. Balanço da bossa e outras bossas. 2a. ed., São Paulo: Perspectiva, 1974.

RUSSELL, Tony. Blacks, Whites, and Blues. In: OLIVER, Paul; RUSSELL, To- ny et al. Yonder Comes the Blues. Cambridge University Press, 2001: 143-242.

SAMPAIO, D. et al. "Este é o cantor mais discutido de 1963". Entrevista concedida por Jorge Ben à Revista do Rádio, publicada em 28/09/1963. In: Sítio de entrevistas de música brasileira Gafieiras.com.br na Internet. Disponível em: <http://www. gafieiras.com.br/Display.php?Area $=$ Colu nas $\&$ SubArea $=$ Home $\&$ css $=1>$. Acesso em: 3 dez. 2006.

TÁVOLA, A. Nara Leão - o canto da resistência. Disponível em: http://www. arturdatavola.com/Senado/ESCRITOR/L ivros/naraleao.htm $>$. Acesso em: $7 \mathrm{dez}$. 2006.

VELOSO, Caetano. Verdade tropical. São Paulo: Companhia das Letras, 1997.

\section{Resumo}

Nos estudos da MPB dos anos 1960, estabeleceu-se uma narrativa hegemônica que atribui a esse movimento um caráter "de cúpula" e retrógrado, enquanto idealiza a Tropicália como o ápice da evolução musical. Identificando nessa narrativa problemas como o evolucionismo e a ideologia da identidade nacional, este artigo propõe a revisão da história do período a partir dos métodos histórico e etnográfico, utilizando exame de documentos, entrevistas e análise etno/musicológica de canções. Conclui-se que a participação popular foi importante para a $\mathrm{MPB}$, terreno contraditório que produziu identidades complexas e colocou em questão a ideologia mestiça e a dominação patriarcal.

Palavras-chave: MPB; Tropicália; 1960.

\section{Abstract}

In the studies about 1960's MPB, a hegemonic narrative was established, according to which MPB was a reactionary movement instituted "from above", while Tropicália is idealized as the apex of musical evolution. Identifying in this narrative problems like evolutionism and the ideology of national identity, this essay proposes a revision of the history of the period 
through the historic and ethnographic methods, using document analysis, interviews, and ethno/musicological song analysis. The conclusion is that popular participation was important to MPB, a contradictory terrain that produced complex identities, and put into question the mestizo ideology and patriarchal domination.

Key words: MPB; Tropicália; 1960.

\section{Résumé}

Dans les études sur la MPB des années 1960, une narrative hégémonique a été établie, selon laquelle ce mouvement avait un caractère rétrograde et "d'imposition", tandis que la Tropicália est idéalisée comme le sommet de l'évolution musicale. En identifiant dans cette narrative des traits d'évolutionnisme et de l'idéologie de l'identité nationale, cet article propose la révision de cette narrative à partir des méthodes historiques et ethnographiques, en utilisant l'examen de documents, interviews et analyse ethno/musicologique de chansons. Nous concluons que la participation populaire a été importante pour la MPB, terrain contradictoire qui a produit des identités complexes et a mis en question l'idéologie métisse et la domination patriarcale.

Mots-clés: MPB; Tropicália; 1960. 